\title{
SEROPREVALENCE OF Toxoplasma gondii (Nicole \& Manceaux, 1909) AND RETROVIRAL STATUS OF CLIENT-OWNED PET CATS (Felis catus, Linnaeus, 1758) IN RIO DE JANEIRO, BRAZIL
}

\author{
Bethânia Ferreira BASTOS(1), Beatriz BRENER(2), Liza GERSHONY(1), Liliane WILLI(3), Norma LABARTHE(4), \\ Cássia PEREIRA(4) \& Flavya MENDES-DE-ALMEIDA(1)
}

\begin{abstract}
SUMMARY
Cats, as definitive host, play an important role in the transmission of Toxoplasma gondii. This study aimed to establish the seroprevalence of anti-T. gondii immunoglobulins G and M, and determine the frequency of oocysts in the feces of the domestic cat population in Rio de Janeiro, Brazil. We also aimed to study the association between $T$. gondii infection and age, sex, breed, lifestyle, diet and retroviral infection. A total of 108 cats were included in the study and fecal samples of 54 of those cats were obtained. Only $5.6 \%$ of the cats were seropositive for anti- $T$. gondii immunoglobulins using the indirect hemagglutination test. None of the 54 cats presented oocysts in their fecal samples. Although not statistically significant, males, mixed-breed, free-roaming and cats aged two years and older were found to be more exposed. Age, lifestyle and the use of litter boxes were found to play an important role as risk factors. Anemia and retroviral infections were independent of $T$. gondii infection. No antibodies were detected in the majority of cats (94.4\%), indicating that those cats had never been exposed to the parasite and, therefore, once infected, they could present the risk of shedding large numbers of oocysts into the environment.
\end{abstract}

KEYWORDS: Toxoplasma gondii; Cats; Indirect hemagglutination; Seroprevalence; Oocysts; Retroviruses.

\section{INTRODUCTION}

Toxoplasma gondii is a zoonotic intracellular protozoon parasite, with a worldwide distribution, that can infect a variety of cell types from a wide range of mammals and birds, including humans ${ }^{2,15,20,21}$. Cats are the definitive host of $T$. gondii and are therefore able to excrete oocysts. Oocysts become infective after 48-72 hours in the environment ${ }^{5}$. The sporulated oocyst may infect different intermediate hosts, which can harbor infective tissue cysts ${ }^{11}$.

Cats generally remain subclinical, but may develop nonspecific clinical signs, including fever, weight loss, dyspnea, polypnea, jaundice, abdominal discomfort, uveitis, retinochoroiditis and neurological abnormalities $^{8}$. In immunocompetent cats, $T$. gondii infection typically leads to latent infection, whereas immunosuppressed cats may develop disseminated toxoplasmosis ${ }^{1,4}$.

The use of serological tests to detect specific antibodies against $T$. gondii is the initial and primary method for indirect diagnosis and is required for epidemiological studies ${ }^{6,13,19}$.

Seroprevalence has been estimated in a number of studies using different tests and thresholds. Reported prevalence rates in cats from Brazil range from 10.2 to $87.3 \%$, varying with the cat's age and lifestyle ${ }^{9,22}$.
Serological diagnosis for $T$. gondii infection in cats relies on the detection of immunoglobulin $\mathrm{M}$ ( $\operatorname{IgM}$ ) and immunoglobulin $\mathrm{G}(\operatorname{IgG})$. The presence of detectable IgM titers indicates active (or reactivated) infection, while a single specific IgG titer indicates prior exposure to antigens only ${ }^{16}$.

Since oocysts are small in size and are shed for a limited period, the chance of detecting them is also small, with oocysts being detected in the feces of $<1 \%$ of cats $^{5}$. Furthermore, oocysts can be misdiagnosed if only based on morphological key features, given their similarity in shape and size to other coccidian parasites, such as Hammondia hammondi ${ }^{4}$. Confirmation with Polymerase Chain Reaction (PCR) or by bioassay is needed ${ }^{7}$.

The aim of this study was to estimate the seroprevalence of anti- $T$. gondii immunoglobulin $\mathrm{G}$ and immunoglobulin $\mathrm{M}$, and the frequency of oocysts in the feces of a domestic cat population in Rio de Janeiro, Brazil. We also aimed to study the association between the $T$. gondii infection and age, sex, breed, lifestyle, diet and retroviral infection of the cats.

\section{MATERIALS AND METHODS}

Cats presented to a free spay-neuter program in Rio de Janeiro, Brazil, were included in the study between May 2009 and August 2010, following owners' consent. Information, such as age, gender, breed, diet, access to 


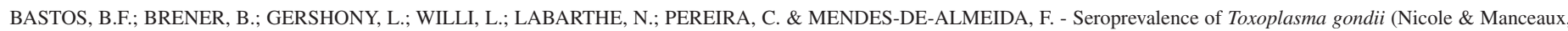
1909) and retroviral status of client-owned pet cats (Felis catus, Linnaeus, 1758) in Rio de Janeiro, Brazil. Rev. Inst. Med. Trop. Sao Paulo, 56(3): 201-3, 2014.

the street, use of litter box and contact with other animal species, were recorded for each animal.

Blood samples were obtained and an aliquot was stored in anticoagulant [Ethylene diamine tetraacetic acid (EDTA)] for determining the presence of anemia (hematocrit $\leq 24 \%$ ) and Feline Immunodeficiency Virus (FIV)/Feline Leukemia Virus (FeLV) infection (Snap Combo, Lab. Idexx). Another aliquot was allowed to clot and centrifuged for serum removal, which was frozen at $-20{ }^{\circ} \mathrm{C}$ until processing.

All serum samples were screened by indirect hemagglutination (Toxo Hai, Lab Analisa Brasil) and those presenting hemagglutination at 1:16 were considered reactive. Reactive samples were then tested for IgM (Toxo Hai, Lab Analisa Brasil). This test is simple in principle and widely used in epidemiological surveys, although not as sensitive when compared with other serologic tests, such as enzyme-linked immunosorbent assay (ELISA) or indirect immunofluorescence (IFI) ${ }^{17}$.

All cat owners were asked to collect fresh fecal samples, which were stored in Raillet \& Henry's solution (formalin/acetic acid) until processed. Fecal samples were examined by two flotation techniques: saturated sugar solution ${ }^{14}$ and zinc sulphate solution ${ }^{10}$.

Identification data, frequency of anti-T. gondii $\mathrm{IgG}$ and $\mathrm{IgM}$, oocysts and packed cell volume were recorded in a data bank and analyzed by both chi-square $\left(\chi^{2}\right)$ and Fisher's Exact Tests, using the Epiinfo 6.01 (CDC, Atlanta, USA) statistical package. The results were considered significant when $p<0.05$, with estimation of the $95 \%$ confidence interval.

\section{RESULTS}

A total of 108 cats were included in the study and 54 fecal samples were obtained from these cats.

Only $5.6 \%$ of cats (6/108) were seropositive for $\mathrm{IgG}$, thus having been infected by $T$. gondii. Three cats presented titers of 1:256, two had titers of 1:128 and one cat presented a titer of 1:64. None of these six cats tested positive for IgM. None of the 54 cats presented oocysts in their fecal samples.

Although not statistically significant, males $(8.82 \%-3 / 34)$, purebred $(14.28 \%-1 / 7)$, free-roaming $(6.55 \%$ - 4/61) and cats aged two years and older $(15 \%$ - 3/20) were found to be more exposed than females $(4.05 \%$ $3 / 74)$, domestic shorthair $(4.95 \%-5 / 101)$, indoors $(4.25 \%-2 / 47)$ and cats younger than two years of age $(3.4 \%-3 / 88)$, respectively. Five cats were anemic (4.6\%) and, among those, only one was seropositive. Toxoplasma gondii infection was found to be independent of retroviral infection, since $1.85 \%$ of cats were infected with FIV (2/108) and 7.4\% with FeLV (8/108), and only one FeLV positive cat was seropositive for $T$. gondii.

The use of sanitary litter boxes appears to prevent, given that all six seropositive cats had never used them, according to owners' information, $\left(\chi^{2}=5.88 ; p=0.005\right)$, while $59.3 \%$ of the cats included in the study $(64 / 108)$ used litter boxes.

\section{DISCUSSION}

Only $5.6 \%$ of the cats were seropositive, while all other studies in
Brazil have found prevalence rates above 10\%. In 2007, the authors published a report on $T$. gondii seroprevalence of an urban colony of free-roaming cats in Rio de Janeiro. These animals were serologically tested for $T$. gondii antibodies, by indirect hemagglutination test and the seroprevalence varied from $92 \%$ to $61 \%{ }^{18}$. Another survey including 41 free-roaming cats from urban areas of the city of Niterói, RJ, concluded that $24.4 \%$ of the cats were seropositive by the same test ${ }^{12}$. When these results are compared to the low rate detected in the present report, it can be attributed to the characteristics of the feline populations included in the studies, suggesting that pet-owned cats are most likely fed on processed food, therefore being indirectly protected from $T$. gondii infection.

It must also be mentioned that age played a role on the results presented. Exposure to T. gondii seems to be dependent upon time, as would be expected. As cats grew older, their chances of becoming infected increased. Lifestyle was found to play an important role as a risk factor, given that free-roaming cats were able to predate intermediate hosts and, therefore, become infected. Anemia and retroviral infections were independent of T. gondii infection and rare, suggesting that most cats were well cared for. Since cats included in this study had their lifestyle determined by their owners, it is possible that females were kept indoors while males were allowed time in the outdoors, particularly when the population included in the study had owners concerned with litters and willing to avoid them. Another issue that may reflect the owners' care for the animals is the use of litter boxes. Well cared for cats have access not only to good quality food and water, but also to a clean environment, including litter boxes. As previously reported, the use of daily cleaned litter boxes is recommended for all cats.

The fact that oocysts were not detected in any of the 54 samples indicates that, although $T$. gondii is widely spread and may be shed by felids in large numbers during a short period of time, animals included in the study had either never been infected (seronegative) or had eliminated the parasite at one time and, by the time they had their fecal samples collected and examined, the shedding period had ended. No antibodies could be detected in the majority of cats $(94.4 \%)$, indicating that these cats had never been exposed to the parasite and therefore, if not properly cared for, could be infected and present the risk of shedding large numbers of oocysts into the environment.

Despite being a well-known parasite, $T$. gondii remains a public health problem worldwide. Therefore, veterinarians must be prepared to elucidate questions and educate their clients pursuing a family commitment with the environmental cleanliness and the care for their pets.

\section{RESUMO}

\section{Soroprevalência da infecção por Toxoplasma gondii (Nicole \& Manceaux, 1909) e a infecção por retrovírus em população urbana de gatos domésticos (Felis catus, Linnaeus, 1758) no Rio de Janeiro, Brazil}

Os gatos, como hospedeiros definitivos, apresentam um papel fundamental na transmissão do Toxoplasma gondii. Nosso estudo teve como objetivo determinar a presença de imunoglobulinas G e M anti-T. gondii, e a frequência de oocistos nas fezes de uma população de gatos domésticos do Rio de Janeiro, Brasil. Objetivou-se ainda estudar a 
BASTOS, B.F.; BRENER, B.; GERSHONY, L.; WILLI, L.; LABARTHE, N.; PEREIRA, C. \& MENDES-DE-ALMEIDA, F. - Seroprevalence of Toxoplasma gondii (Nicole \& Manceaux, 1909) and retroviral status of client-owned pet cats (Felis catus, Linnaeus, 1758) in Rio de Janeiro, Brazil. Rev. Inst. Med. Trop. Sao Paulo, 56(3): 201-3, 2014.

associação da infecção por T. gondii com a idade, sexo, raça, estilo de vida, dieta e infecção por retrovírus. Um total de 108 gatos foi incluído no estudo e 54 amostras de fezes foram obtidas desses animais. Somente $5,6 \%$ dos gatos foram sororreagentes para $T$. gondii, utilizando-se o teste de hemaglutinação indireta. Nenhum dos 54 gatos apresentou oocistos em suas amostras fecais. Embora sem comprovação estatística, machos, sem raça definida, com acesso livre às ruas e gatos com mais de dois anos de idade tenderam a ser mais expostos ao parasito. Idade, estilo de vida e uso de caixa de areia foram considerados importantes fatores de risco. Anemia e infecção por retrovírus não apresentaram relação com infecção por $T$. gondii. Não foram detectados anticorpos na maioria dos gatos $(94,4 \%)$, indicando que esses gatos nunca foram expostos ao parasito e que, se infectados, poderão eliminar grande número de oocistos no ambiente.

\section{REFERENCES}

1. Davidson MG, Rottman JB, English RV, Lappin MR, Tompkins MB. Feline immunodeficiency virus predisposes cats to acute generalized toxoplasmosis. Am J Pathol. 1993;143:1486-97.

2. Dubey JP, Miller N, Frenkel JK. The Toxoplasma gondii oocyst from cat feces. J Exp Med. 1970;132:636-62.

3. Dubey JP, Frenkel JK. Immunity to feline toxoplasmosis: modification by administration of corticosteroids. Vet Pathol. 1974;11:350-79.

4. Dubey JP, Beattie CP. Toxoplasmosis of animals and man. Boca Raton: CRC Press; 1988. 220 p.

5. Dubey JP. Toxoplasmosis and other coccidial infections. In: Sherding R.G. The cat diseases and clinical management. $2^{\text {nd }}$ ed. New York: Churchill Livingstone; 1994. p. 565-605.

6. Dubey JP. Validation of the specificity of the modified agglutination test for toxoplasmosis in pigs. Vet Parasitol. 1997;71:307-10.

7. Dubey JP, Lappin MR. Toxoplasmosis and neosporosis. In: Greene CE, editor. Infectious diseases of the dog and cat. $2^{\text {nd }}$ ed. Philadelphia: WB Saunders; 1998. p. 493-503.

8. Dubey JP, Lappin MR. Toxoplasmosis and neosporidiosis. In: Greene CE, editor. Infectious diseases of the dog and cat. $3^{\text {rd }}$ ed. St Louis: Saunders Elsevier; 2006. p. 754-768.

9. Dubey JP, Lago EG, Gennari SM, Su C, Jones JL. Toxoplasmosis in humans and animals in Brazil: high prevalence, high burden of disease and epidemiology. Parasitology. 2012;139:1375-424.
10. Faust EC, D’Antoni JS, Odom V, Miller MJ, Perez C, Sawitz W, et al. A. A critical study of clinical laboratory technics for the diagnosis of protozoan cysts and helminth eggs in feces. Am J Trop Med. 1938;18:169-83.

11. Frenkel JK, Dubey JP, Miller NL. Toxoplasma gondii in cats: fecal stages identified as coccidia oocists. Science. 1970;167:893-6.

12. Gonçalves Netto E, Munhoz A, Albuquerque G, Lopes C, Ferreira A. Ocorrência de gatos soropositivos para Toxoplasma gondii Nicolle e Manceux,1909 (Apicomplexa Toxoplasmatinae) na cidade de Niterói, Rio de Janeiro. Rev Bras Parasitol Vet. 2003; 12:145-9.

13. Hill D, Dubey JP. Toxoplasma gondii: transmission, diagnosis and prevention. Clin Microbiol Infect. 2002;8:634-40

14. Huber F, Silva S, Bomfim TC, Teixeira KR, Bello AR. Genotypic characterization and phylogenetic analysis of Cryptosporidium sp. from domestic animals in Brazil. Vet Parasitol. 2007;150:65-74

15. Jacobs D, Dubremetz JF, Loyens A, Bosman F, Saman E. Identification and heterologous expression of a new dense granule protein (GRA7) from Toxoplasma gondii. Mo Biochem Parasitol. 1998;91:237-49.

16. Mancianti F, Nardoni S, Ariti G, Parlanti D, Giuliani G, Apini R. Cross-sectional survey of Toxoplasma gondii infection in colony cats from urban Florence (Italy). J Feline Med Surg. 2010;12:351-4

17. Meireles LR, Galisteo AJ Jr, Pompeu E, Andrade HF Jr. Toxoplasma gondii spreading in an urban area evaluated by seroprevalence in free-living cats and dogs. Trop Med Int Health. 2004;9:876-81.

18. Mendes-de-Almeida F, Labarthe N, Guerrero J, Faria MC, Branco AS, Pereira CD, et al Follow-up of the health conditions of an urban colony of free-roaming cats (Felis catus Linnaeus, 1758) in the city of Rio de Janeiro, Brazil. Vet Parasitol. 2007;147:9-15.

19. Montoya JG. Laboratory diagnosis of Toxoplasma gondii infection and toxoplasmosis J Infect Dis. 2002;185(Suppl 1):S73-82.

20. Sedlák K, Bártová E. Seroprevalences of antibodies to Neospora caninum and Toxoplasma gondii in zoo animals. Vet Parasitol. 2006;136:223-31.

21. Sobrino R, Cabezon O, Millan J, Paboni M, Arnal MC, Luco DF, et al. Seroprevalence of Toxoplasma gondii antibodies in wild carnivores from Spain. Vet Parasitol. 2007; 148:187-92

22. Sogorb F, Jamra LF, Guimarães EC, Deane MP. Toxoplasmose espontânea em animais domésticos e silvestres, em São Paulo. Rev Inst Med Trop Sao Paulo. 1972;14:314-20.

Received: 17 July 2013

Accepted: 10 October 2013 